\title{
【論文】
}

\section{新型コロナウイルス感染症（COVID-19）危機の酪農乳業への影響と 需給調整システム}

\section{北海道大学 清水池 義治}

\section{The Impact of the COVID-19 Crisis on Japan's Dairy Industry and the Supply-Demand Adjustment System}

\author{
Yoshiharu SHIMIZUIKE \\ Hokkaido University
}

\begin{abstract}
:
Japan's dairy industry has a characteristic supply-demand adjustment system based on quantitative adjustment rather than price adjustment, and it has responded to the huge supply-demand fluctuations caused by the COVID-19 crisis. This study aims to identify the challenges facing the dairy industry's supply and demand adjustment system by analyzing the impact of the COVID-19 crisis on the industry and its response to the crisis.

Supply-demand adjustment to the COVID-19 crisis has kept milk disposal and significant price declines under control. However, systemic risks have emerged, such as restrictions on milk supply during summer, reduced capacity to adjust supply and demand because of instability in dairy production, and imbalances in the burden of supply-demand adjustment costs. While a wide range of actors enjoy the benefits of supply-demand adjustment, the costs are concentrated in a few actors. The method of sharing the costs of reducing dairy inventories will be determined through negotiations between the actors, including the government, which will take some time but may have the advantage of making the costs visible to the actors. COVID-19 has brought about a form of crisis that has amplified the problems that have traditionally plagued the supply-demand adjustment system. If it proves difficult to share the adjustment costs among the actors, a permanent system in which the government compensates for costs will be necessary.
\end{abstract}

Keywords: COVID-19 crisis, dairy industry, supply-demand adjustment, systemic risk, Japan

\section{1. 問題の所在と課題設定}

日持ちしない生乳を扱う酪農乳業にとって、需 給調整は重要な課題のひとつである。日本の酪農 乳業における需給調整は、主に(1)「指定団体」と 呼称される政策的に組織された農協連合会（註1） と乳業メーカーとの間の生乳取引、(2)国家貿易に よる脱脂粉乳・バターなどの輸入管理、(3)生乳の
計画生産（減産・生産抑制は大幅な需給緩和時の み)、を通じて行われている (矢坂, 2016 ; 清水池, 2019b）。価格変動を前提とする欧米諸国と比べ た場合の日本の特徴は、価格変動を可能な限り回 避するために、数量調整に依存した需給調整手法 が採用されている点である（註2）。特に、1990年 代以降、生乳の減産や生産抑制を避けるため、指 定団体と乳業メーカーとの間で行われる、脱脂粉 乳・バター用途をバッファとした生乳の用途間分 
配調整の精緻化が進められてきた（矢坂，2016； 清水池, 2019b; 清水池, 2015)。しかし、近年 では、専ら数量調整に依存した需給調整の限界性 が指摘されている（矢坂, 2016 ; 清 水池, 2019a ; Shimizuike, 2014 ; 小田, 2020)。

ところで、サプライチェーンの寸断によって需 給調整の混乱が見られた東日本大震災や北海道胆 振東部地震といった自然災害時 (矢坂, 2013 ; 清 水池ら，2021）と比較して、2020年春からの新型 コロナウイルス感染症（以下、COVID-19）危機 は以下の特徴を有する。第1にサプライチェーン は健在だったが劇的な需要減少を中心とする影響 が生じた、第2にその需要への影響は品目間の差 が大きく、「まだら模様」(小池，2020）だった点 である。加えて、COVID-19危機は、欧米諸国と 日本の酪農乳業に対照的な状況をもたらしている (矢坂, 2021)。多くの欧米諸国では、2020年春の ロックダウンで急激な需要減少・在庫増加・価格 下落と、大規模な生乳廃棄が発生したものの、同 年後半には好調な輸出市場を受けて価格・需要と もに急回復し、楽観的な市場見通しが示されてい る(IDF, 2020)。一方、日本でも急激な需要減 少・在庫増加が起きたが、大きな価格下落や生乳 廃棄は生じなかった。ただし、在庫水準は高止ま りし、需要回復は弱いままである（矢坂，2021： 小田, 2020)。この対照性は、日本の需給調整シ ステムのいかなる特徵を反映したものであろうか。

本論文の課題は、COVID-19危機が酪農乳業に 及ぼしている影響とその危機 対応の分析を通じて、酪農乳 業の需給調整システムが孕む 問題を明らかにすることであ る。

以上の課題を明らかにする ため、まず、2節では本論文 の分析方法を示す。次に、3 節でCOVID-19危機下の需給 変動を統計デー夕から分析す る。続いて、4節で需給調整 システムの具体的対応と影響 を期間区分して検討した後、 5節にてCOVID-19危機で見え

出所：筆者作成
てきた需給調整システムの孕むシステミック・リ スクを論じる。

\section{2. 分析方法}

1）酪農乳業の需給調整システム

図1は、日本の酪農乳業における需給調整シス テムの概念図である。

都府県と北海道の間には、生乳の用途による役 割分担が存在する。生乳の用途は、飲用乳向けと 乳製品向け（クリームやチーズ、脱脂粉乳・バ夕 一など）に大別される。人口の大多数が居住する 都府県に飲用乳工場の大半が、北海道に乳製品工 場の大半が立地する。そのため、都府県の指定団 体の供給する生乳の $77 \%$ が飲用乳向け、一方、北 海道の指定団体の供給する生乳の78\%が乳製品向 けである（2020年度、中央酪農会議「用途別販売 実績」)。

基本的な需給調整の枠組みを述べる。(1)都府県 の指定団体は、日持ちせず需要変動の大きい飲用 乳向け生乳を、乳業メーカーの必要量に応じて優 先分配する。(2)都府県だけでは飲用乳向け需要を 満たせないため、不足量に応じて北海道の指定団 体から都府県へ飲用乳向け生乳が移出される。(3) 北海道の指定団体は、都府県移出と飲用乳・クリ ーム・チーズ向けを優先分配した後の残余分とし て、脱脂粉乳・バター向け生乳（註3）を北海道 内の工場へ供給する。北海道における用途間の優

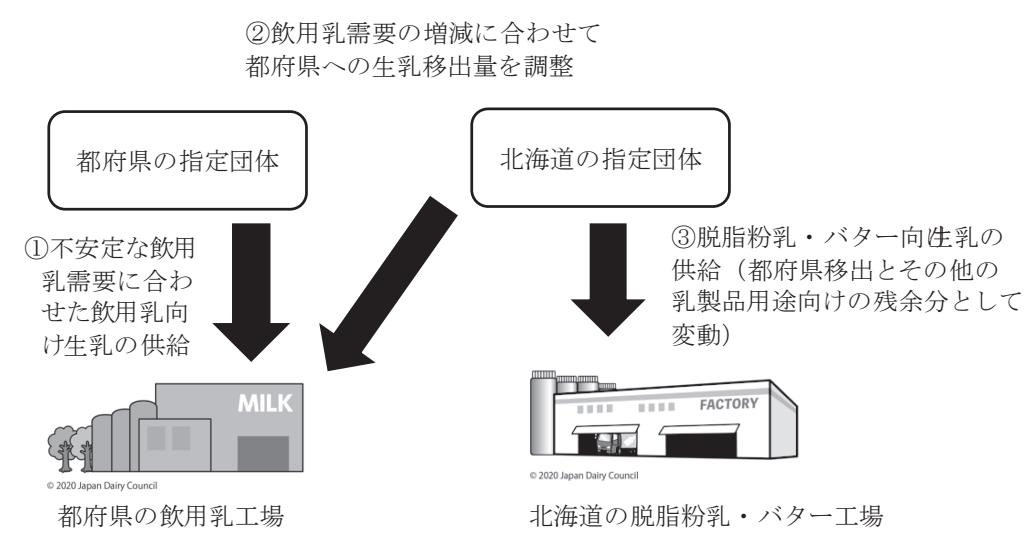

図1酪農乳業の需給調整システム（概念図） 
先順位は、基本的には需給調整の必要性と乳価水 準に基づく。最優先される用途は、日持ちせず乳 価の最も高い飲用乳向け（都府県移出＋道内工場 向け)、次に優先される用途は、飲用乳向けと同 様に日持ちしないが、飲用乳向けよりは乳価の低 いクリーム・脱脂濃縮乳向けで、両用途は乳業メ 一カーの必要量に応じて分配される。脱脂粉乳・ バター向けは、保存性が高く在庫調整や輸入によ る補填が可能でかつ乳価が低いため、需給調整の 緩衝用途として優先順位は最も低くなっている (註4)。

毎年起きる飲用乳需要の季節変動を例に、需給 調整システムの対応を説明すると、夏季の需給逼 迫時は飲用乳需要が増えるため、都府県での不足 が強まり、北海道から都府県への移出量が増える。 その結果、北海道での脱脂粉乳・バター向け生乳 の供給が減り、工場稼働率は低下する。逆に、春 先の需給緩和時は飲用乳需要が減り、また生乳生 産の増加する時期であるため、都府県での不足が 弱まり、北海道から都府県への移出量が削減され る。その結果、北海道での脱脂粉乳・バター向け 生乳の供給が増え、工場稼働率は上昇する。当然 飲用乳需要の季節変動以外でも需給変動は起きる が、システムの対応は基本的に同様である。

本論文では、COVID-19危機が、以上の需給調 整システムの対応にいかなる影響を及ぼしている かを分析する。

\section{2）分析対象とデータ}

分析対象期間は、日本国内でCOVID-19の本格 的な流行が始まる2020年2月を期間中に含む、 2020年1月から 2021 年3月までを基本とする。

分析対象とする地域は、都府県の中でも最大の 飲用乳生産地・消費地である関東地域とし、北海 道との間での需給調整を検討する。分析対象とし た乳業メーカーは、都府県の飲用乳メーカー、な らびに都府県と北海道で需給調整機能を有する乳 製品メーカーの典型的な事例である。本研究は関 東対象の事例分析であるが、都府県は概ね飲用乳 主体の地域であると同時に、指定団体・乳業メー カー間の取引関係、あるいは乳業メーカー間の役 割分担は都府県で共通するため、分析結果は都府
県の他地域にも妥当すると考えられる。

使用デー夕は、第1に農林水産省「牛乳乳製品 統計」などの公的統計、中央酪農会議や指定団体、 乳業メーカーの公表資料など、第2に需給調整シ ステムを構成する主体へのヒアリングを通じて入 手した。

ヒアリング対象は、都府県では、関東地域の指 定団体である関東生乳販売農業協同組合連合会 (以下、関東生乳販連) 、指定団体と乳業メーカー 間の需給調整を仲介する全国農業協同組合連合会 (以下、全農)、関東地域に飲用乳工場を持つ大手 乳業メーカーA、乳製品工場で余乳処理を担当 する乳業メーカーB、北海道では、北海道の指定 団体であるホクレン農業協同組合連合会（以下、 ホクレン)、北海道に乳製品工場を持つ大手乳業 メーカーC・Dであり、いずれも2021年4月から5 月にかけてオンライン、あるいは対面形式でヒア リングを実施した。

\section{COVID-19危機による需給変動}

\section{1）牛乳・乳製品需要への影響}

本節では、COVID-19危機による需給変動とそ の特徴を検討する。

図2は、2020年における生乳需給の対前年比増 減を生乳換算量で示した。供給は生乳生産、需要 は牛乳等向け（註5）・クリーム向け・脱脂濃縮乳 向け・チーズ向けへの各生乳仕向け量、脱脂粉乳 とバターは推定出回り量から生乳換算量を算出し た。

図中の緊急対策とは、COVID-19の影響による 需要減少で在庫が増加した脱脂粉乳を対象に、政 府の実施した需要創出による在庫削減対策を指す。 具体的には、国産脱脂粉乳の飼料転用や輸入調製 品との置き換えのために行われる、脱脂粉乳、あ るいは同用途向け生乳の価格引き下げ補填である。 図では、脱脂粉乳は見かけ上はわずかな需要増だ が、これは緊急対策による在庫削減を加味した結 果である。2020年度内の在庫削減効果は製品重量 で1.8万t（註6）、生乳換算で約11.6万tに相当する。 よって、対策がない場合、脱脂粉乳の需要は 1.3

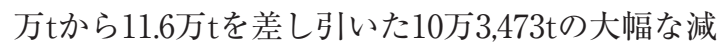


新型コロナウイルス感染症（COVID-19）危機の酪農乳業への影響と 需給調整システム

少となる。

需要が減少した品目は、減少量 の大きい順に、脱脂粉乳（政府の 緊急対策なしの場合)、バター、 業務用牛乳等、クリーム、脱脂濃 縮乳、チーズである。減少要因は、 外出自肃による外食・観光需要の 減少や土産用途で多い菓子需要の 減少が考えられる。逆に需要が増 加した品目は、業務用以外、つま り家庭向けの牛乳等である。牛乳 等の増えた要因は、外出自肃によ る「巣ごもり需要」の増加や官民 挙げた消費拡大キャンペーンの影 響が指摘できる（Jミルク，2021）。

このように需要への影響は品目 差が大きく、「まだら模様」と言 える。需要はトータルで見ると減 少で、生乳生産が前年比で12万t 超も増加した（緩和要因）ことと

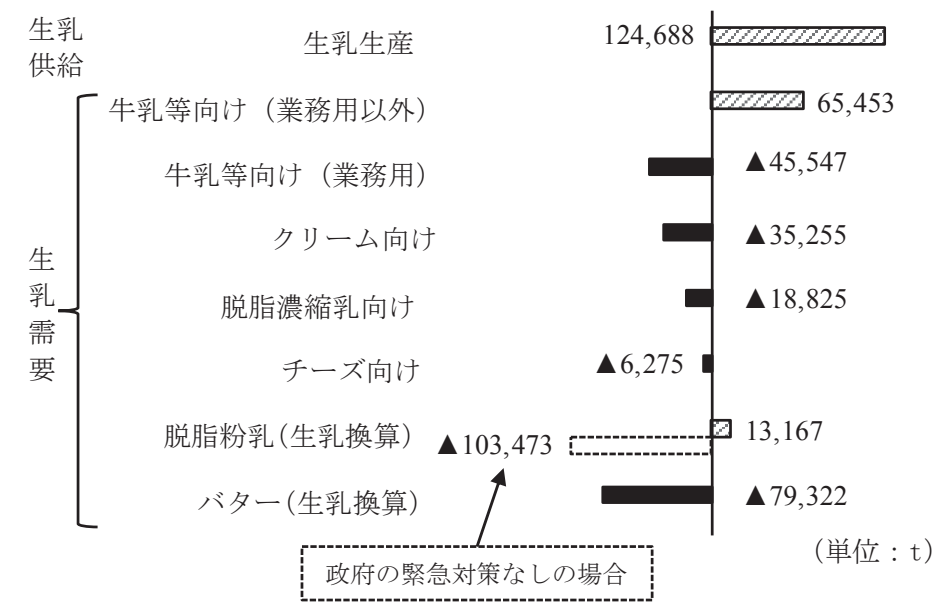

図2 2020年における生乳需給の増減量（生乳換算、2019年比） 出所 : 農林水産省「牛乳乳製品統計」より筆者作成

註：1）脱脂粉乳とバターは推定出回り量（輸入品含む）から生乳換算し て求めた。これら以外の用途は国産生乳仕向け量である（輸入品 は含まない)。

2）チーズには在庫があるので需要減少を必ずしも意味しない。

3）脱脂粉乳は政府の緊急対策で在庫削減が行われている。 相まって、需給は年間で見た場合、 大幅に緩和した。

\section{2）乳製品在庫の増加}

図3は、脱脂粉乳とバターの期末在庫量（3月末 時点）の推移である。2020年度末の脱脂粉乳とバ ターの在庫量は、過去最高水準に達している。脱 脂粉乳は2019年度末から約5,000t増加して8万 1,175tである。前述の緊急対策で約 $1.8 万 \mathrm{t} の$ 在庫 削減が行われていることを考えると、実質的に、 2003年度を超える10万t程度だったと言える。バ ターも、2019年度末から実に約1万tも増加して3 万 8,862 tとなり、1999年度と同程度となった。記 録的な需給緩和と言える。

このような需給状況下でも、乳業メーカーの受 乳拒否や処理不能による生乳廃衰は一切行われて いないほか、指定団体による生乳の計画減産・生 産抑制も予定されていない。

COVID-19危機が始まった2020年春以降、価格 もほとんど変化がない。脱脂粉乳とバターの大口 需要者価格はほぼ一定である（農林水産省「主要 乳製品の価格動向」)。また、2020年後半から2021

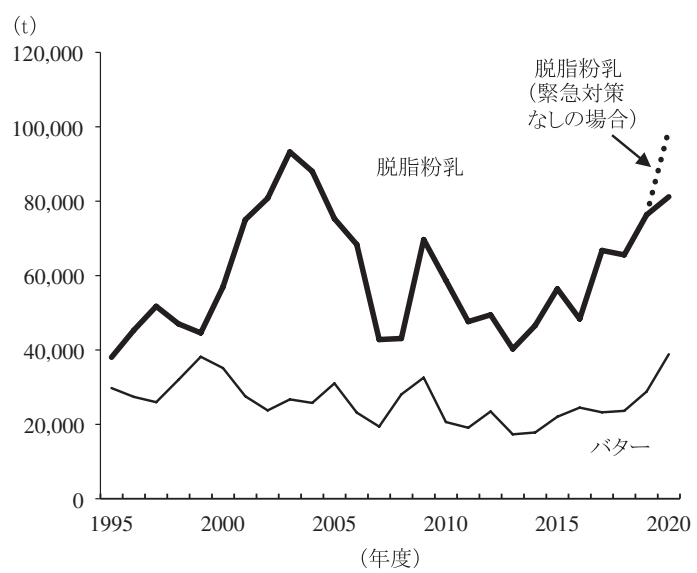

図3脱脂粉乳とバターの推定期末在庫量(3月末時点) 出所：農林水産省「牛乳乳製品統計」

年度乳価交渉が行われたが、全用途で乳価が据え 置きとなった。このように、今回の危機下でも、 価格安定を目的とした需給調整システムは有効に 機能しているように見える。 


\section{4. 需給調整システムの対応とその影響}

1）期間区分と主体間関係

本節では、COVID-19危機による需要ショック に需給調整システムがどのように対応したかを述 ベ、システムへの影響を検討する。

生乳の需給は、飲用乳需要と生乳生産の各々の 季節変動を反映して、通常の場合でも春先に需給 緩和、夏から秋口にかけて需給逼迫が生じる。

そこで、COVID-19に対する政府の感染対策を 踏まえ、分析期間を以下の3つに区分する。全国 一斉休校で学校給食が停止された2020年3月から 学校給食停止と1回目の緊急事態宣言が継続した5 月までを(1)第1次需給緩和期（2020年3月～5月）、 緊急事態宣言が解除され学校給食が再開された 6 月から始まる飲用乳需要期を(2)需給逼迫期（2020 年6月～10月)、11月以降を(3)第2次需給緩和期 (2020年11月以降) とする。

図4に、本報告で調查対象となった主体の関係 性を示した。

関東地域に工場を持つ乳業メーカー (大手乳業 メーカーA）に生乳を委託販売するのは、基本 的に関東地域の指定団体である関東生乳販連であ る。ただし、北海道など関東地域外の指定団体か ら移入される生乳は、全農（あるいは全酪連）が 仲介して乳業メーカーへ販売される。乳業メーカ 一は関東生乳販連から定時定量で生乳を購入して 飲用乳を製造するが、飲用乳の需要減によって生 乳の全量処理が困難である場合、余乳処理機能を 有するメーカー(乳業メーカーB $)$ へ脱脂粉乳 · バターの委託加工を依頼する。余乳処理メーカー と全農（あるいは全酪連）は緊密に連携して、余 乳処理を実施する（註7）。

北海道では、北海道の指定団体であるホクレン が、北海道に工場を持つ乳業メーカー (大手乳業 メーカーC・D） へ生乳を委託販売するとともに、 全農へ再委託販売する形態で都府県に生乳を移出 する。

2）各期間の需給調整システムの対応

分析に用いる基本的なデー夕を図 5 と図6に示し

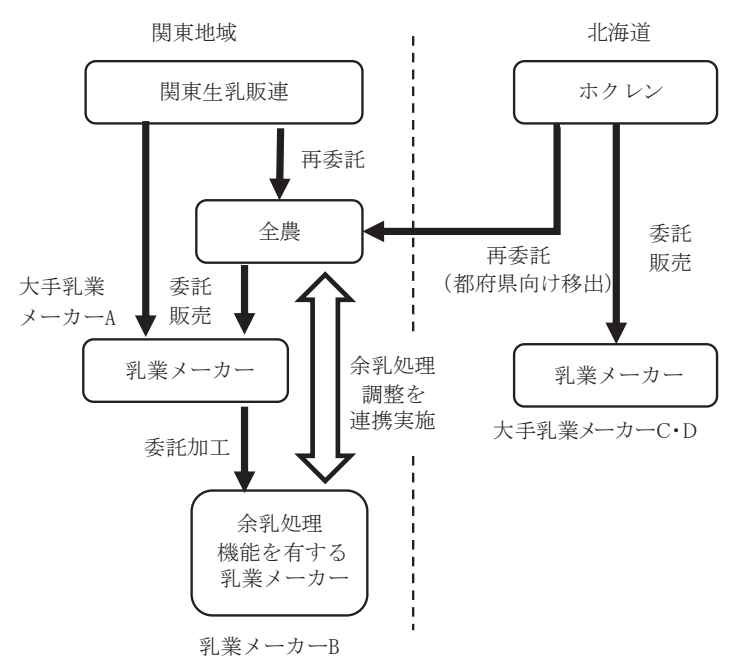

図4 分析対象の主体間関係

出所 : 筆者作成

た。月別の処理量・販売量で、2019年・2020年 ・ 2021年（3月まで）の実績である。なお、2019年 の数值は、2020年以降のCOVID-19危機による影 響を読み取るための比較対象として示した。2019 年は、直近年であるとともに、通常の季節的な需 給変動とは異なる顕著な変動のない年であるため、 比較対象年として適切と判断した。

図5は、関東地域の生乳の用途別処理量である。 関東立地工場における生乳の処理数量で、関東外 から移入された生乳や指定団体以外の事業者の取 り扱う生乳も含まれる。図6は、ホクレンによる 生乳の用途別販売量である。ホクレンが販売する 生乳のみで、ホクレン以外の事業者の取り扱う生 乳は含まれない。

(1)第1次需給緩和期：2020年3月〜 5 月

この期間では需要減少によって、過去に例のな い需給緩和が長期間、継続した。

COVID-19危機における最初の需要ショックは、 2020年3月上旬に開始された全国一斉休校による 学校給食向け牛乳（以下、学乳）の供給停止であ った。続いて、4月中旬には緊急事態宣言が全国 に発出され、外出自肃や休業要請が特に外食需要 に大きく影響した。その結果、関東では牛乳等向 け処理量の約1割を占める業務用牛乳が最大で3割 減少(対前年同月比)、北海道では業務用比率の 


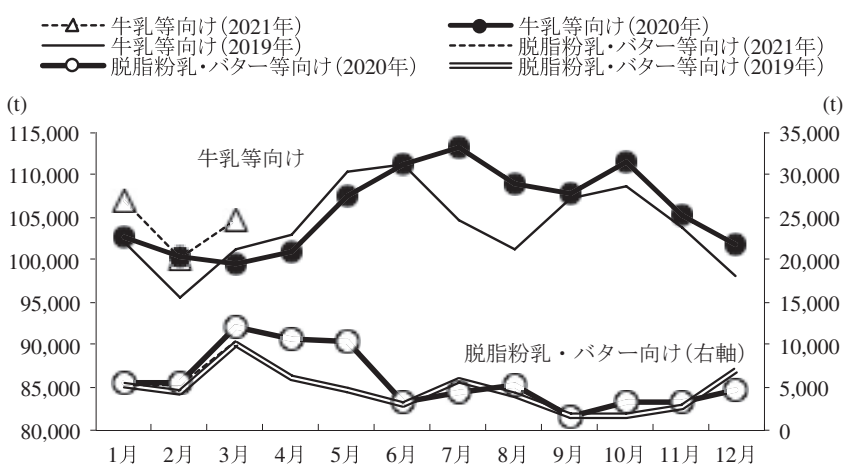

図5関東地域の生乳の用途別処理量

出所：農林水産省「牛乳乳製品統計」

註：1）関東地域の工場で処理された生乳の実績值で、関東外から移 入された生乳、指定団体以外の事業者が取り扱う生乳を含む。

2）関東地域は関東農政局管内の1都9県で、関東生乳販連の事業 領域と同一である。

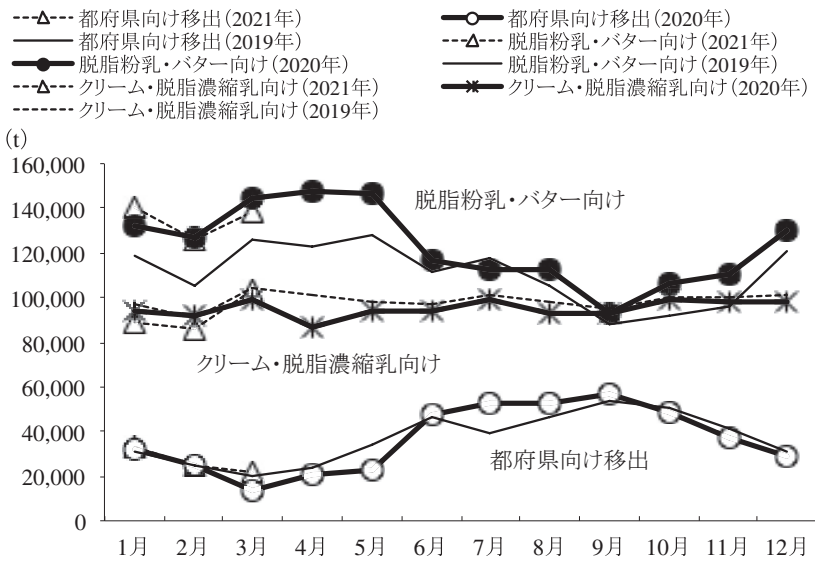

図6 ホクレンによる生乳の用途別販売量

出所：ホクレン「指定生乳生産者団体情報」

註：1）ホクレンが委託販売を行なった生乳の実績值のみで、ホ クレンを経由しない生乳は含まれない。

高いクリーム・脱脂濃縮乳向けが最大で2割減少 （対前年同月比）した。これを受け、生乳廃異の 回避を最優先の目的として、脱脂粉乳・バターを 中心とする乳製品の生産を増やす対応が行われた。 「経済合理性を度外視」(大手乳業メーカーC) し てとにかく乳製品を増産したが、それを可能とし たのは政府による緊急対策の措置があった。

都府県で余乳処理機能を持つ乳業メーカーBは、 フル稼働の状態が3月から5月までの3か月間続い た。4月中旬以降は緩和傾向がさらに強まって、
余乳処理メーカーだけでは対応できな くなり、通常は余乳処理を行わないメ ーカーでも余乳処理を行った。脱脂粉 乳・バター向け処理量は、通常年であ れば3月のみが突出して多くなるが、 2020年は、上限に近い1万t超の処理量 が3月から5月まで3か月間も継続した (図5)。特に4月と5月は、2019年比で3 割から10割も多くなっている。ただし、 業務用牛乳の減少が乳製品増産に直結 したわけではなく、4月中旬以降は消 費拡大キャンペーンや「巣ごもり」の 影響で家庭用牛乳の消費が増え、減少 分の相殺効果があった。この相殺効果 がなければ、生乳廃裹の可能性があっ たとも指摘される。

北海道でも、都府県の需給緩和を受 けた都府県向け移出の削減やクリー 厶・脱脂濃縮乳向けの減少、そして生 乳生産が前年より増えていることもあ り、脱脂粉乳・バター向けが大きく伸 張した（図6）。現状で上限と考えられ る月間 15 万に近い販売量が 3 月から 5 月まで続いた。特に困難な時期は、4 月中旬から5月中旬であった。通常、 前旬（註8）までに配乳調整の大枠は 完了しているが、前々日、前日になっ ても配乳先が未定となっている事態が 度々発生した。5月には北海道の乳製 品工場への負荷を下げるため、都府県 向け移出を上積みして都府県に乳製品 生産を分担してもらう対応策も採られ た。

5月下旬になり、緊急事態宣言の解除見通しが 出てくると、需要の回復傾向が見られるようにな り（事前注文数量の増加）、需給緩和傾向は弱ま っていった。

(2)需給逼迫期：2020年6月～10月

前の期間の大幅な需給緩和から一転して、2020 年6月以降は急激かつ大幅な需給逼迫が生じた。

6 月上旬の緊急事態宣言解除によって、学乳供 
給が再開されるとともに、経済活動の正常化で業 務用を含む飲用乳や業務用乳製品の需要が回復し てきた。そのような中で、6月下旬に北海道から の都府県向け移出がフル稼㗢となっても供給が追 いつかなくなり、通常年と比べて長い6月から 10 月まで、需給逼迫がほぼ継続する事態となった。 都府県の牛乳等向け処理量は6月には前年並みま で回復、7月と8月は1割程度増加、それ以降も前 年を超える傾向が続いた（図5）。夏休み期間の学 乳停止で、通常、7月と8月は处理量の低下が見ら れるが、2020年は夏休み期間の短縮措置でその傾 向は弱まった。一方、脱脂粉乳・バター向けは6 月以降、一気に前年水準まで低下した（図5)。北 海道の脱脂粉乳・バター向けは5月まで前年を大 きく超えていたが、6月以降は前年水準まで低下 したのに対して、都府県向け移出はフル稼働に近 い月間5万水準が6月から10月まで続いた（図6）。

この需給逼迫の要因は、都府県の生乳生産が前 年同月比で減少が続いた一方での飲用乳需要の堅 調、夏休み期間短縮で通常は供給量が少ない7 月・8月における学乳供給の多さ、8月以降の猛暑 による生乳生産減、8月をピークとする感染拡大、 いわゆる「第2波」による「巣ごもり」需要の増 加などである。

すでに6月下旬から、都府県向け移出の事前注 文数量が移出可能量を超え、注文数量の調整が行 われてきたが、梅雨の長期化で飲用乳需要が抑制 され、一定の逼迫水準に留まってきた。しかし、

8月上旬の梅雨明け後の猛暑と8月下旬の生乳生産 の減少は、需給逼迫をさらに深刻化させた。9月 に入ると、飲用乳向け生乳の供給制限が強化され、 乳業メーカー各社は、量販店向けのナショナル • ブランド $(\mathrm{NB})$ 牛乳を中心に $10 \%$ 台から $20 \%$ 台 にかけての供給削減を実施した。例えば、大手乳 業メーカーAは、NB牛乳の欠品に加え、プライ ベート・ブランド (PB) 牛乳の $10 \%$ から $20 \%$ 削 減といった襒しい対応を強いられた。いずれも過 去にない水準の供給制限である。通常、9月の飲 用乳最需要期に向けて、都府県の乳業メーカーは 工場の貯乳タンクに数量調整用の「繰越乳」(清水 池ら, 2021 : p.23) を積み増していく。しかし、 2020年は、7月から続く需給逼迫によって繰越乳
の事前積み増しができず、十分な備えができない まま最需要期に入り、過去にない供給制限を行わ ざるをえない一因となった。

次に、北海道における需給逼迫への対応である。 ホクレンは、最需要期の都府県向け移出の一時的 な増加に対して、運送業者とのスポット契約で生 乳輸送を行ってきた。7月下旬・8月の夏休み期間 短縮に備えて、その時期のドライバーや輸送車両 （トレーラーヘッドなど）を確保してきたが、6月 下旬にはすでに移出はフル稼働体制となった。本 来は他の農産物の移出時期と競合し、人員 - 車両 の事前想定を超えるスポット的な確保は難しかっ たものの、COVID-19危機の影響で農産物の荷動 きが停滞していたためにある程度は対応できたが、 それでも関東地域における牛乳の大幅な供給制限 を防げなかった。北海道からの移出能力の制約が 需給調整のボトルネックになったと言える。また、 フル稼働時に都府県移出が一時的に止まった場合、 影響が長期化する問題が改めて浮き彫りになった。 9 月下旬の台風12号の影響で、太平洋航路の生乳 輸送フェリーが4日間、欠航した。フル稼働時の 久航は、翌日以降の移出量上積みで久航時の欠損 分を補填できないため、実際の移出量が注文数量 を下回る状態が続くことになり（清水池ら, $2021:$ p.23)、この場合でも10月下旬まで影響が 残った。

10月に入ると、生乳生産が回復、加えて気温低 下による飲用乳需要が減少し、極端な需給逼迫は 収まっていった。

\section{(3)第2次需給緩和期：2020年11月以降}

通常年であれば、10月から12月末にかけてはク リスマスに向けた乳製品最需要期、それ以降は年 末年始と 3 月末の春休み期間に学乳停止による一 時的な需給緩和が生じる期間である。しかし、 2020年シーズンは、以下のようにやや異なる傾向 となった。

都府県の牛乳等向け処理量は11月以降も前年同 月を上回る状況で、2021年1月と3月は2020年の同 月と比べても $5 \%$ 程度、増加している。一方、脱 脂粉乳・バター向けは前年とほぼ同じとなった （図5）。北海道の都府県向け移出は概ね前年並み 
だが、2021年3月は前年より大きく増加した。脱 脂粉乳・バター向けは生乳生産の増加を背景とし て、2020年中は前年を超えて推移し、2021年1月 以降は大幅な需給緩和であった2020年水準に匹敵 する数量となっている。クリーム・脱脂濃縮乳向 けは2020年末には前年並みまで回復したものの、 翌年1月・2月は2020年同月を割り込んだ（図6）。 業務用乳製品の需要回復に向けた動きは未だ明確 ではないと言える。

都府県の飲用乳需要の堅調さにより、当初懸念 されていた年末年始と春休み期間の需給緩和がほ とんど起きない異例の事態となった。年末年始は 首都圈での感染再拡大と重なり、帰省自肃による 在宅時間の増加は「巣ごもり需要」を喚起した。 北海道では、2020年末のクリスマスに向けた業務 用乳製品の引き合いが好調で、都府県向け移出と の競合に対する調整が必要となり、12月中旬まで 需給逼迫の傾向が見られた。ただ、依然として脱 脂粉乳・バター向け販売量は高止まりし、2021年 3 月にかけ、脱脂粉乳と比べて在庫対策が遅れて いたバター在庫が積み上がった。

\section{(4)小括}

COVID-19危機下の需給調整システムの対応の 特徴は以下の通りである。

第1に、COVID-19の感染状況を受けた政府の 対策や人々の行動変容によって、生乳需給の従来 有している季節変動が増幅、あるいは軽減された 結果、十分な需給調整ができなかった点である。 2020 年春の需給緩和時と 2020 年 9 月の逼迫時が、 その端的な事例である。過去に例のない需給変動 を示したため、予測困難で事前準備が不十分とな り、需給調整に困難を来した思われる。

第2に、需給変動の極端化である。COVID-19 対策としての外出自肃は、飲用乳需要を押し上げ る一方で、外食需要の多い業務用乳製品の需要を 減少させる作用がある。つまり、季節的な需給逼 迫時の外出自鹔は飲用乳需要を増加させ、事前想 定を超えて都府県の飲用乳需給を逼迫させるが、 北海道から都府県への移出能力が機敏に増強でき ないと需給逼迫への対応が困難になる。加えて、 需給緩和時の外出自肃は、乳製品需要減少によっ
て北海道の需給状況をさらに緩和させる。このよ うに、COVID-19危機は季節的な需給変動を増幅 させ、需給調整システムの対応に困難な影響をも たらすと考えられる。

3）緊急対策による需給調整コストの補填

COVID-19危機を受け、国やホクレンは相次い で緊急対策を実施した。以下では、対策による需 給調整コストの補填状況を確認する。

\section{(1)緊急対策の内容}

表1に、政府とホクレンによるCOVID-19に関 する緊急対策の内容を示した（需給調整に関わる ものに限定)。

まず、政府の緊急対策は4つある。

学校給食用牛乳の供給停止に伴う需給緩和対策 事業（事業期間：2020年2月27日～6月12日、予算 額：91億円。以下同じ）は、学校給食停止による 学乳向けから脱脂粉乳・バター向けへの生乳の用 途転換に伴う生産者乳価の下落補填と、その結果 として製造された脱脂粉乳・全粉乳を飼料転用す る際の価格差補填から構成される。支援対象は前 者が生産者、後者が乳業メーカーで、上限数量は 脱脂粉乳7,400tである。

生乳需給改善促進事業（2020年4月17日～2021 年3月31日、50億円）は、乳業メーカー保有の脱 脂粉乳・全粉乳を飼料転用か輸入調製品との置き 換えで処理する際の価格差補填で、支援対象は乳 業メーカー、上限数量は脱脂粉乳1万 $4,200 t$ であ る。

生乳需給調整緊急支援事業（2020年4月7日～5 月25日、19億円）は、需給緩和を受けてチーズ・ バター・全粉乳向け処理量を増やした乳業メーカ 一に対し保管費用相当分として協力金（50円 $/ \mathrm{kg}$ 以内）を支給する内容で、支援対象は乳業メーカ ーである。

国産乳製品需要拡大緊急対策事業（2021年1月 28日～2022年3月31日、17億円）では、乳業メー カーによるバターの新規販売、あるいは輸入調整 品との置き換えを支援する。支援対象は乳業メー カー、上限数量はバター8,000tである。

次に、ホクレンの緊急対策は2つある。 
フードシステム研究第 28 巻3号 2021.12

表1 政府とホクレンによるCOVID-19緊急対策

\begin{tabular}{|c|c|c|c|c|c|c|}
\hline & 事業名 & 期間 & 予算額 & 支援対象 & 実施主体 & 内容 \\
\hline \multirow{4}{*}{$\begin{array}{l}\text { 政 } \\
\text { 府 }\end{array}$} & $\begin{array}{l}\text { 学校給食用牛乳 } \\
\text { の供給停止に } \\
\text { 伴う需給緩和 } \\
\text { 対策事業 }\end{array}$ & $\begin{array}{l}2020 \text { 年 } 2 \text { 月 } 27 \text { 日 } \\
\sim 6 \text { 月 } 12 \text { 日 }\end{array}$ & 91億円 & $\begin{array}{l}\text { 生乳生産者、 } \\
\text { 乳業メーカー }\end{array}$ & $\begin{array}{l}\text { 中央酪農会議、 } \\
\text { 全農、全酪連、 } \\
\text { 日本乳業協会な } \\
\text { ど }\end{array}$ & $\begin{array}{l}\text { 学乳から脱脂粉乳・バター向けへの用途転 } \\
\text { 換に伴う乳価下落補填、学乳停止で製造さ } \\
\text { れた粉乳の飼料転用に伴う価格差補填（脱 } \\
\text { 脂粉乳7,400t対象） }\end{array}$ \\
\hline & $\begin{array}{l}\text { 生乳需給改善 } \\
\text { 促進事業 }\end{array}$ & $\begin{array}{l}\text { 2020年4月17日 } \\
\text { ～2021年3月31日 }\end{array}$ & 50億円 & 乳業メーカー & 日本乳業協会 & $\begin{array}{l}\text { 乳業メーカー保有の粉乳の飼料転用、輸入 } \\
\text { 調製品との置き換え時の価格差補填（脱脂 } \\
\text { 粉乳1万 } 4,200 \text { t対象） }\end{array}$ \\
\hline & $\begin{array}{l}\text { 生乳需給調整 } \\
\text { 緊急支援事業 }\end{array}$ & $\begin{array}{l}\text { 2020年4月27日 } \\
\text { ～5月25日 }\end{array}$ & 19億円 & 乳業メーカー & 全農、ホクレン & $\begin{array}{l}\text { チーズ・バター・全粉乳向け処理拡大の乳 } \\
\text { 業に対して協力金 }(50 \text { 給 } / \mathrm{kg} \text { 以内、保管費用 } \\
\text { の一部相当) 支給 }\end{array}$ \\
\hline & $\begin{array}{l}\text { 国産乳製品需要 } \\
\text { 拡大緊急対策 } \\
\text { 事業 }\end{array}$ & $\begin{array}{l}\text { 2021年1月28日 } \\
\sim 2022 \text { 年3月 } 31 \text { 日 }\end{array}$ & 17億円 & 乳業メーカー & $\begin{array}{l}\text { 全農、日本乳業 } \\
\text { 協会、全国農協 } \\
\text { 乳業協会など }\end{array}$ & $\begin{array}{l}\text { 乳業メーカー製造のバターの新規販売、輸 } \\
\text { 入調製品との置き換えに協力金支給（バ } \\
\text {-8,000t対象） }\end{array}$ \\
\hline \multirow{2}{*}{$\begin{array}{l}\text { ホ } \\
\text { ク } \\
\text { ン }\end{array}$} & $\lceil 12$ 億円対策」 & 2021年1月～3月 & 12億円 & 乳業メーカー & ホクレン & $\begin{array}{l}\text { 乳業メーカーが基準数量を超えて購入した } \\
\text { 乳製品向け生乳を対象に、在庫費支援、輸 } \\
\text { 入品との置き換えを図るために乳価引き下 } \\
\text { げ }\end{array}$ \\
\hline & 「80億円対策」 & $\begin{array}{l}\text { 2021年4月 } \\
\sim 2022 \text { 年3月 }\end{array}$ & 80億円 & 乳業メーカー & ホクレン & $\begin{array}{l}\text { 乳業が基準数量を超えて購入する乳製品向 } \\
\text { け生乳（バ夕ー7,000t、脱脂粉乳 1万垷当) } \\
\text { を対象に、輸入品との置き換えを図るため } \\
\text { に乳価引き下げ }\end{array}$ \\
\hline
\end{tabular}

出所：農林水産省ホームページ、ホクレン「北海道指定生乳生産者団体情報」

註：需給調整に関係する対策に限定している。

2020年12月に発表された「12億円対策」(2021年 1月〜3月、12億円）は、乳製品在庫の金利倉敷料 相当の一部、ならびにチーズなど国産乳製品の輸 入チーズとの置き換えを図る目的で、乳業メーカ 一が基準数量を超えて購入した乳製品向け生乳の 乳価を引き下げる内容である。続く2021年3月発 表の「80億円対策」(2021年4月～2022年3月、80億 円）では、輸入チーズや輸入調製品との置き換え を図るため、乳業メーカーが基準数量を超えて購 入したチーズ向けや、脱脂粉乳・バター向けなど の生乳（対象生乳は約 15 万t : バター7,000t、脱脂 粉乳1万t相当）の乳価を引き下げる措置となった。

\section{(2)緊急対策の特徵とコスト補填}

COVID-19危機の生起直後から矢継ぎ早に打ち 出された政府による一連の緊急対策は、その全て が、需給安定に関わる法制度に基づくものではな い臨時対策（農畜産業振興機構事業）として措置 された。よって、サプライチェーンを構成する指 定団体や乳業メーカーは事前に対策の内容を想定 していなかった。これらの緊急対策は、今回限り の暫定措置と言える。また、政府の臨時対策とし ては、事業規模は大きい。単純合計すると177億 円で、酪農政策の中心である加工原料乳生産者補 給金制度の単年度事業額の約5割に相当する。酪
農以外の他品目と比べても手厚い内容である。

学校給食用牛乳の供給停止に伴う需給緩和対策 事業の一部を除き、政府の緊急対策の直接的な支 援対象は乳業メーカーである。ただし、これら対 策は、乳製品生産を促進して生乳廃棄を回避、あ るいは在庫削減によって乳価下落を防止するなど、 あくまでも生産者への影響緩和を目的としている。 ホクレンの対策は、限定的な乳価引き下げによっ て、乳業メーカーの需給調整コストの一部を生産 者で負担する性格を持つ。

学乳から脱脂粉乳・バター向けへの用途変更に 伴う乳価下落補填の実施により、都府県の生産者 乳価への影響はほぼ解消された。一方、ホクレン の「12億円対策」と「80億円対策」の実施で、北 海道の生産者乳価はそれぞれ生乳1 kgあたり 30 銭、 2 円ほど下落する影響が生じる。政府の緊急対策 で部分的に補填されるものの、生産者の手取り乳 価は低下している。また、北海道に工場を持つ乳 業メーカーは乳製品在庫の増大、そして在庫削減 に伴う需給調整コストを負担しているが、政府と ホクレンの緊急対策でその全てが補填されてはい ない（註9）。よって、COVID-19危機による需給 調整コストの負担状況には差があると言える。 


\section{5. 需給調整システムのシステミック・リスク}

本節では、COVID-19危機で浮き彫りになった 酪農乳業の需給調整システムのシステミック・リ スクを論じる。ここで言うシステミック・リスク は、システムの一部の破綻がシステム全体の崩壊 につながるリスクという意味で用いている。

1）飲用乳需要期における牛乳供給制限の常態化

第1に、飲用乳需要期の牛乳の供給制限が常態 化している。

従来、需要期における都府県の飲用乳需要は、 北海道からの生乳移出の増加で対応してきた。こ こ数年における生乳輸送フェリーの更新や輸送夕 ンク大型化で移出可能量は数值上、上昇したもの の、2020年は事前想定を超えたため、北海道内の 生乳輸送を行うドライバーと輸送車両の確保がボ トルネックとなり、移出能力に限度が生じた。

1990年代半ば以降の都府県の生乳生産減少と北 海道の生乳生産増加、その一方での飲用乳需要の 下げ止まりと2015年以降の微増傾向への変化によ って、都府県における飲用乳向け生乳の供給不足 を補うための都府県向け移出の必要量は増してい る。しかし、都府県向け移出が一定水準に制約さ れると、需要期における牛乳供給の制限が常態化 し、都府県向け移出のフル稼動期間が長期化する ことになる。

図7は、2000年から2020年までのホクレンの都 府県向け移出量の月別変動である。2010 年以前は、飲用乳最需要期の9月を頂点 とする山型の季節変動であった。だが、 2020年には、需要期を通じて移出可能量 近くに張り付く台形型の季節変動へと変 化した。2015年、2019年もすでに同様の 傾向だが、2020年には季節変動がさらに 大きく、かつフル稼働期間が長くなって いる。

都府県向け移出可能量は、現状水準が 上限ではない。2020年の月間移出可能量 は6.3万tであったが、タンク数増加・大 型化で2021年は9月を念頭に同・6.4 6.5 万tまで増加、計画的投資を通じて数年以内に 同・7万tを目標としている（ホクレンヒアリン グ）。移出量の増加と季節変動の拡大、フル稼働 期間の長期化で移出コストは増大傾向にある。現 在、移出コストは共販経費を通じて北海道の生産 者が主に負担しているが、今後の移出体制維持の ためには都府県 (特に購入者である乳業メーカー) とのコスト負担のあり方が課題と言われている。

2）乳製品生産の不安定化による需給調整の対応 能力の低下

第2に、北海道における乳製品生産の不安定化 である。COVID-19危機で季節的な需給緩和・逼 迫が極端化することで、脱脂粉乳・バター製造工 場の稼働率の季節変動がさらに拡大している。

1980年代に構造化した生乳の需給緩和を受けて、 ホクレンは脱脂粉乳・バター向け生乳の供給を減 らし、飲用乳向けとクリーム・脱脂濃縮乳向けの 供給を増やす長期的な対応を 30 年近く行ってきた （清水池, 2015：pp.82-84）。その結果、ホクレン 販売量に占める脱脂粉乳・バター向け比率は6割 から4割以下まで低下し、絶対量も190万tから 140 万埄割り込むまでに減少した。

図8は、1990年から2020年までのホクレンの脱 脂粉乳・バター向け生乳販売量の月別変動である。 脱脂粉乳・バター向けは長期的に減少傾向にある が、2020年には季節変動が明瞭に大きくなってい る。これは、脱脂粉乳・バター製造を行う乳業メ ーカーにとって、工場稼働率の絶対水準が長期的

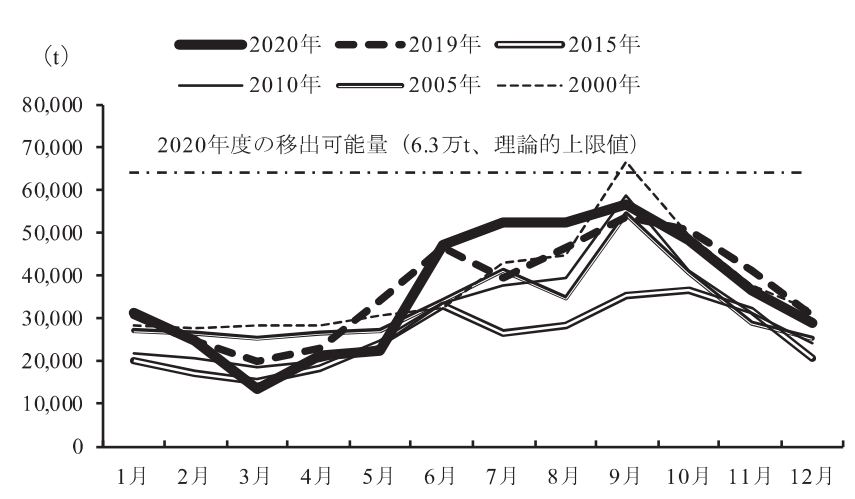

図7 ホクレンの都府県向け移出量の月別変動 出所：ホクレン「北海道指定生乳生産者団体情報」 
に低下する中での稼働率の季節変動の 増大を意味する。

この間の脱脂粉乳・バター生産の不 採算化の結果、一部メーカーでは工場 設備への投資 ·更新が停滞し、設備老 朽化が進んでいる場合もある。加えて、 一部メーカーでは、工場の低稼働状態 を前提とした従業員配置とせざるを得 ないため、一時的な工場稼働率の引き 上げに対して本来の設備能力を下回る 限度が生じることになる。これらの点 が、一時的ではあるが極端な需給緩和 への対応力を低下させる要因となって いる。

一方、脱脂粉乳・バターから輸入競 合の小さいクリーム・脱脂濃縮乳へ置 き換えるホクレンの対応は、貿易自由 化対策の性格もある（清水池, 2015： p.84）。近年相次ぐ経済連携協定の発 効で、国産乳製品と輸入品との競合が さらに強まると予想される。脱脂粉 乳・バ夕ー向け（需給調整用途）とク リーム・脱脂濃縮乳向け（貿易自由化 対策用途）との用途構成のバランスが 今後の課題である。

\section{3）需給調整コスト負担の不均衡}

第3に、COVID-19危機では需給調整コスト負 担の不均衡が改めて浮き彫りになった。1つに北 海道と都府県との間の地域的な不均衡、いま1つ に乳業メーカー間での不均衡である。

前者はすでに触れたため、後者について言えば、 脱脂粉乳・バターの生産比重の高い特定の大手乳 業メーカーに需給調整コストが集中する構造とな っている。このメーカー間格差は、ホクレンが長 期的に進めてきた前述のクリーム・脱脂濃縮乳向 け増加対策に、一部の大手メーカーのみが積極的 に対応してきた結果として生じてきた（清水池, 2015：pp.104-111）。2020年度現在の大手乳業メ 一カーの脱脂粉乳・バター向け比率（註10）を比 較すると、Cの58\%、Dの $62 \%$ に対し、Eは $34 \%$ 、 Fは $43 \%$ と差がある。

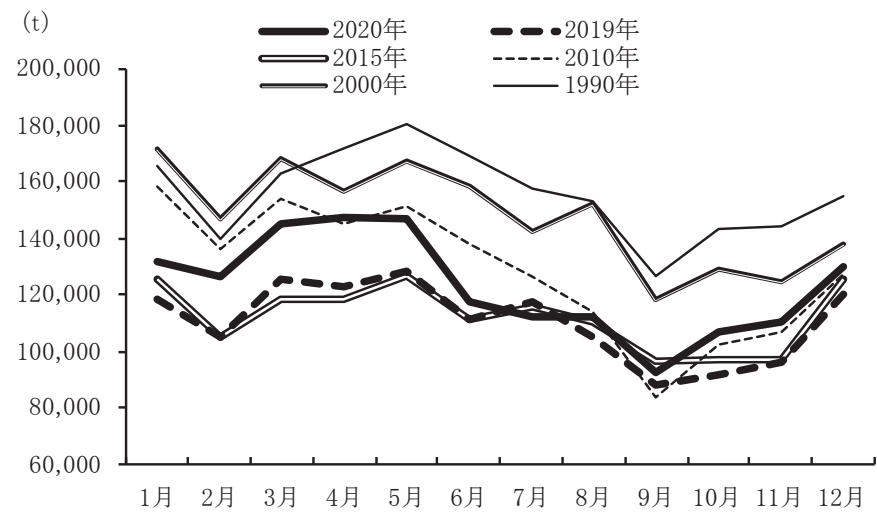

図8 ホクレンの脱脂粉乳・バター向け生乳販売量の月別変動 出所：ホクレン「北海道指定生乳生産者団体情報」

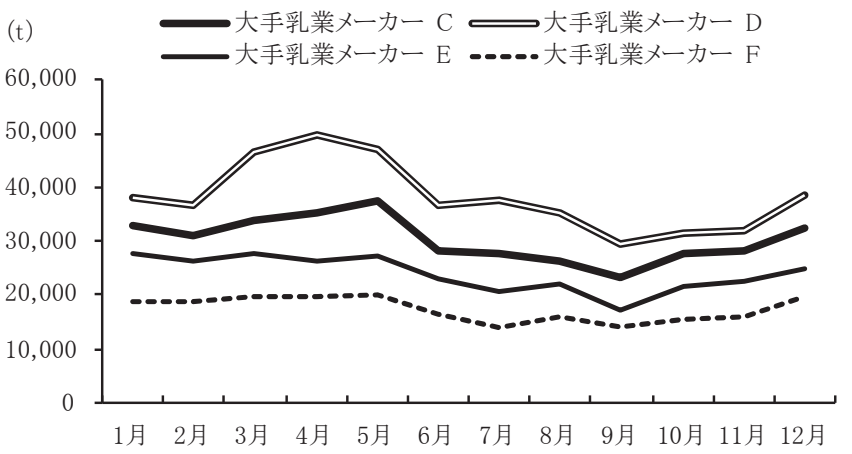

図9 大手乳業メーカーの脱脂粉乳・バター向け購入量の月別 変動（北海道、2020年）

出所 : ホクレン「北海道指定生乳生産者団体情報」

図9に、2020年の北海道に抢ける大手乳業メー カーの脱脂粉乳・バター向け生乳購入量の月別変 動を示した。2020年春の需給緩和時に、購入量を 増加させて需給調整に対応しているのは大手乳業 メーカー C・Dの2社だけで、季節変動も大きい と分かる。一方、 $\mathrm{E} \cdot \mathrm{F}$ 購入量はほぼ変化せず、 季節変動も小さい。

現状の需給調整システムは、最終的には脱脂粉 乳・バターの数量調整で帳尻合わせを行う。よっ て、この数量調整は需給調整システムの要である。 しかし、特定の少数メーカーだけが脱脂粉乳・バ ターの数量調整を担う体制（註11）は、需給調整 システムそのものを崩壊させるリスクを高めると 言える。実際に、該当するメーカーからは、工場 の低稼働率に起因する高コス卜構造による競争上 の不利や将来的な事業継続の困難さが指摘されて 
いる（大手乳業メーカー C・Dヒアリング）。

すなわち、需給調整を担う乳業メーカーがコス 卜負担に耐えかねて、上限なく脱脂粉乳・バター の製造を引き受ける役割を拒否、あるいは遂行で きなくなった場合、現行の方法での数量調整が不 可能となり、欧米のような価格調整を前提とした 調整システムへ移行せざるを得なくなる。現在、 乳価は、現行の数量調整システムもあり、需給動 向というょり生乳生産費といった要素で変動する (清水池, $2017:$ p.47)。脱脂粉乳・バター向け乳 価が市況に応じて変動するようになると、同用途 との価格序列で価格形成がなされる飲用乳向け （矢坂，2009）など他の用途の乳価へも影響が波 及する。その結果、価格変動を通じて、幅広い主 体が需給調整コストを負担するようになる。数量 調整を前提とした指定団体と乳業メーカーとの取 引関係や乳業メーカー間の役割分担は、根本的な 転換を迫られるだろう。一方で、量販店中心に形 成される牛乳・乳製品の小売価格は需給に対し硬 直的傾向があり（新山, 2020：矢坂, 2009)、価 格調整がサプライチェーン全体で可能か懸念があ る。需給調整コスト負担の不均衡は、このような システミック・リスクを孕んでいるのである。

\section{6. 結論}

COVID-19危機に対応した需給調整の結果、日 本の酪農乳業では、現時点では生乳廃裹や大幅な 価格低下は起きていない。しかし、今回の危機は、 需給調整の便益を享受する主体は幅広い一方、需 給調整の費用負担は一部主体のみに集中している という従来からのシステミック・リスクを改めて 浮き彫りにした。脱脂粉乳・バターによる数量調 整が限度に達した時点で、数量調整に依存したシ ステム全体が崩壊する懸念がある。

COVID-19危機は、酪農乳業に新たな形態の危 機ではなく、需給調整システムに従来から孕まれ ていた問題点を増幅させる形態の危機をもたらし た。日本の酪農乳業の需給調整システムに限って 言えば、COVID-19危機を発端としたパラダイ ム・シフトによる不可逆的な変化が起きているの ではなく（木立, 2020)、むしろ過去の構造問題
への対応によって蓄積されてきた問題が COVID-19危機で表出した危機の要因になってい ると考えられる(Clapp and Moseley, 2020)。 加えて、今回の危機には、需給調整に関わって進 行していた構造問題が強まる時期を前倒しさせる 影響があったと言える。

欧米では、COVID-19危機で生じた損失が、価 格下落と廃裹を通じて比較的短期間のうちに、乳 業メーカーや酪農家など幅広い主体によって負担 されたと言える。当然、酪農家の負担には、乳業 メーカーの集乳拒否によって有無を言わせず押し 付けられたものも含まれる。それに対して、日本 では、限られた主体の費用負担に基づく需給調整 によって損失は表面化することなく、乳製品在庫 の形で先送りされている。積み上がった在庫を誰 の負担で削減するか、政府を含めた主体間の交涉 が行われている最中であり、正常化には一定の時 間を要すると思われる。日本の需給調整は主体間 の交渉を通じ一定の時間をかけて行われる。価格 調整に立脚した欧米と比較すると迅速ではないも のの、一方的な負担の押し付けではなく、交渉を 通じて負担割合の事後的な調整が行われるため、 経済の公正さの面で評価すべき点があるかもしれ ない。

今回の危機では、本論文で対象としなかった需 給調整の方法、すなわち生乳の計画生産と国家貿 易による輸入管理の機能低下も露見した。生乳の 計画生産については、2018年の畜産経営安定法改 正を前後して生産者が指定団体外出荷を行うハー ドルが下がったため、指定団体が生産者の共販離 脱を恐れ、需給緩和時に従来実施してきた生産抑 制や減産といった方法が事実上、不可能になって いる（矢坂, 2021 ; 清水池, 2021)。また、この 間の需給逼迫を受けて官民挙げた生乳増産対策を 行なっている只中であり、増産を妨げる対応はで きないという事情も大きい。一方の国家貿易によ る輸入管理も、需給緩和時は輸入量を減らすのが 従来の対応だったが、長らく需給逼迫が続いてバ ター輸入が定着した結果、輸入バターユーザーに 配慮して政府が輸入量を大きく削減できない事態 となっている (矢坂, 2021)。その結果、残され た唯一の方法である乳業メーカーによる乳製品在 
庫調整に、過去にない大きな負担がかかることに なった。

需給調整システムを構成する主体間の取引を通 じて需給調整コストの負担平準化を図るのが難し いのであれば、政府が需給調整コストを補填する 常設の制度が求められていると言えよう。

（註1）正式名称は指定生乳生産者団体で、1966年度か ら加工原料乳生産者補給金等暫定措置法に基づい て政策的な組織化が進められた。2018年度の法改 正で指定団体の名称はなくなったが、組織実態は 変わらないため、本論文では指定団体の名称を用 いる。

（註2）矢坂（2009）は需給動向を反映しづらい価格形 成の背景、新山（2020）は牛乳小売価格の分析に よって価格が需給調整のシグナルとして機能しづ らい点を指摘する。

（註3）脱脂粉乳・バター向けは、練乳類向けも含むが 量的に多くないため、単に「脱脂粉乳・バ夕ー向 け」と表記する。

（註4）矢坂 (2008）：pp.73-74を参照。なお、全用途 中で最も乳価の低いチーズ向けは手取り乳価全体 への影響を考慮して、指定団体と乳業メーカーが 事前に合意した数量に基づき、計画的に分配され ている。

（註5）牛乳等は、牛乳、成分調整牛乳、加工乳、乳飲 料、発酵乳、乳酸菌飲料を指す（農林水産省「牛 乳乳製品統計」)。

（註6）「脱脂粉乳、年度末在庫抑制も実需弱く危機感」 『酪農スピードNEWS』、2021年5月13日付。

（註7）関東地域外の指定団体から移入される生乳は全 農か全酪連が取り扱うが、北海道からの生乳は全 農のみが取り扱う。余乳となる生乳は、関東生乳 販連から再委託を受けた全農が集出荷を担当する。 飲用乳中心で乳製品の販売ルートを持たない中小 乳業メーカーが余乳処理目的で委託加工した脱脂 粉乳・バターは、全農が買い上げている。

(註8)「旬」は1か月を三等分した期間である。前旬とは、 該当日が中旬の場合は上旬を意味する。

（註9）概算だが、半分以上は補填されている（大手乳 業メーカー C・Dヒアリング)。

（註10）この場合の比率は北海道内の工場で加工され る生乳に占める同用途の割合である。ホクレン 「北海道指定生乳生産者団体情報」より。

（註11）この点は都府県の余乳処理体制も同様だが、
都府県の場合、脱脂粉乳・バター製造の季節変動 の大きさを前提に、脱脂粉乳・バターメーカーだ けがコストを負担しない仕組みとなっている。余 乳処理を行うのは乳業メーカーBなど特定メーカ 一に限定されるものの、委託加工費の形で飲用乳 主体の他の乳業メーカーも需給調整コストを一部 負担するとともに、全農も余乳処理で製造される 乳製品の一部を買い取っている（全農、乳業メー カーBヒアリング)。

\section{引用文献}

Clapp, J. and W. G. Moseley (2020) This Food Crisis Is Different: COVID-19 and the Fragility of the Neoliberal Food Security Order, Journal of Peasant Studies 47(7): 1393-1417.

https://doi.org/10.1080/03066150.2020.1823838

International Dairy Federation (IDF) (2020) The World Dairy Situation 2020, Bulletin of IDF 506.

Jミルク（2021）「牛乳乳製品に関する食生活動向調査 2020：二次調查報告」https://www.j-milk.jp/ report/trends/h4ogb40000005dpm-att/ h4ogb400000064hv.pdf（2021年5月閲覧）.

木立真直（2020）「コロナ禍による食品流通の変容と展 望一パラダイム・シフトの妥当性について一」『農 業と経済』86 (11) : 60-68.

小池恒男（2020)「新型コロナウイルスのパンデミック

はフードシステムにどのような影響をもたらした か』農業と経済』86（11）：41-51.

新山陽子 (2020)「牛乳価格と酪農家の疲弊一小売業者 の低価格販売・消費者の価格判断・市場のパワー バランスー」新山陽子編『フードシステムの構造 と調整』昭和堂：198-218.

小田志保（2020)「酪農乳業における新型コロナウイル スの影響」『農業と経済』86（11）：69-79.

清水池義治・安田驍・戴容秦思 (2021)「地震災害がミ ルクサプライチェーンに及ぼす影響と既存対策の 課題一平成30年北海道胆振東部地震を事例とし て一」『フードシステム研究』28（1）:16-28.

https://doi.org/10.5874/jfsr.28.1_16.

Shimizuike, Y. (2014) Alterations to the Rules on Material Milk Distribution to Milk Processors through Supply Shortages of Domestic Raw Milk, Agricultural Marketing Journal of Japan $22(4)$ : 34-46.

https://doi.org/10.18921/amsj.22.4_34.

清水池義治（2015）『増補版 生乳流通と乳業一原料乳 
新型コロナウイルス感染症（COVID-19）危機の酪農乳業への影響と 需給調整システム

市場構造の変化メカニズム—』デーリィマン社. 清水池義治（2017）「加工原料乳補給金制度の改定要 因一現行の『固定払い』方式の評価を通じて一」 『農業市場研究』26(3) : 43-53.

清水池義治（2019a）「バター不足に対する需給調整政 策の効果一国家貿易制度と臨時対策事業を対象と して一」『フロンティア農業経済研究』21 (2) : 11-25.

清水池義治（2019b）「日本の酪農に係る政策・経済と 酪農の変遷」『農村計画学会誌』38（2）：104-107. https://doi.org/10.2750/arp.38.104.

清水池義治 (2021)「改正畜安法下の生乳流通から見え てきたこと一北海道からの視点一」『農村と都市を むすぶ』71 (2) : 43-51.
矢坂雅充 (2008)「生乳市場は市場のシグナル機能を果 たしているか」『農業と経済』74（6）：70-78.

矢坂雅充 (2009)「乳価形成をめぐる諸問題と改革の方 向性」『都市問題』100（1）: 72-83.

矢坂雅充 $(2013)$ 「ミルクサプライチェーンの震災から の復旧と頑健化への対応」木立真直・齋藤雅通編 著『製配販をめぐる対抗と協調』白桃書房：241267.

矢坂雅充 (2016)「生乳流通問題とは何か一規制改革会 議の議論を超えて一」『農業と経済』82（9）：8-19. 矢坂雅充 (2021)「コロナ禍の酪農乳業と生乳需給調 整」『農村と都市をむすぶ』71（3）：51-63.

[2021年7月21日受付、2021年10月23日受理］ 